\title{
KREATIVITAS DAN KETAHANAN EMOSIONAL PADA SISWA DENGAN EKSKUL MEMBATIK
}

\author{
Evi Afifah Hurriyati ${ }^{1}$; Ratri Dyah Mawarni $^{2}$ \\ Psychology Department, Faculty of Humanities, Universitas Bina Nusantara \\ Jln. Kemanggisan Ilir III No.45, Kemanggisan - Palmerah, Jakarta Barat 11480 \\ 1e_afifah@binus.ac.id; 2tridie_kitty@yahoo.co.id
}

\begin{abstract}
Batik is not only an element of culture and art, but it has creativity. Batik also has the message how to manage our emotions, because in making batik takes perseverance, optimism, cognitive function as well as patience. The aim of this research was to examine the relationship between creativity and emotional resiliency in students grade 4-6 elementary school. Subjects were students of MI Giriloyo 2 Yogyakarta grade 4 to grade 6, which amounted to 62 students. Data retrieval is done by spreading the figural creativity tests to measure creativity variables and emotional resilience questionnaire to measure the variables of emotional resilience. Subjects showed a fairly good creativity with emotional resilience pretty good anyway. Bivariate product moment correlation with SPSS 19.0 for windows between creativity with emotional resilience correlation values obtained at 0.184 and $p=0.153$. Research shows that the zero hypothesis (HO) which states "There is no significant relationship between creativity and emotional resiliency in students MI Giriloyo 2 Yogyakarta" accepted while the alternative hypothesis ( $\mathrm{Ha}$ ) which states "There is a significant relationship between creativity and emotional resilience MI students Giriloyo 2 Yogyakarta" had rejected. Thus, the results showed no relationship between creativity and resilience significant emotions in students with extracurricular studentMI batik Giriloyo 2 Yogyakarta with a very low correlation coefficient. Other variables were not examined by the authors, such as internal and external factors correlated with the subjects supposedly more emotional resilience.
\end{abstract}

Keywords: Students, Batik, Creativity, Emotional Resilience

\begin{abstract}
ABSTRAK
Membatik adalah suatu aktivitas yang tidak hanya mengandung unsur budaya dan seni, namun tedapat pula unsur kreativitas. Membatik juga kental akan pesan bagaimana mengelola emosi kita, karena dibutuhkan ketekunan, optimisme, fungsi kognitif yang baik, serta kesabaran. Penelitian ini bertujuan untuk melihat hubungan antara kreativitas dengan ketahanan emosional pada siswa membatik kelas 4-6 sekolah dasar. Subjek penelitian adalah siswa MI Giriloyo 2 Yogyakarta kelas 4 sampai dengan kelas 6 yang berjumlah 62 siswa. Pengambilan data dilakukan dengan menyebarkan Tes Kreativitas Figural untuk mengukur variabel kreativitas dan kuesioner ketahanan emosional untuk mengukur variabel ketahanan emosional. Subjek penelitian menunjukkan kreativitas yang cukup baik dengan ketahanan emosi yang cukup baik pula. Hubungan korelasi bivariat product moment dengan bantuan program SPSS 19.0 for windows antara kreativitas dengan ketahanan emosional menunjukkan nilai sebesar 0,184 dan $p=0,153$. Hal ini menunjukkan bahwa hipotesis nihil (HO) yang menyatakan "Tidak terdapat hubungan yang signifikan antara kreativitas dengan ketahanan emosional pada siswa MI Giriloyo 2 Yogyakarta” diterima sedangkan Hipotesis alternatif (Ha) yang menyatakan " : Terdapat hubungan yang signifikan antara kreativitas dengan ketahanan emosional pada siswa MI Giriloyo 2 Yogyakarta." ditolak. Dengan demikian hasil penelitian menunjukkan tidak ada hubungan yang sifnifikan antara kreativitas dan ketahanan emosi pada siswa dengan ekstrakurikuler membatik pada siswa MI Giriloyo 2 Yogyakarta dengan koefisien korelasi yang sangat rendah. Variabel lain yang tidak diteliti oleh penulis, seperti faktor internal dan eksternal subjek diduga lebih berkorelasi dengan ketahanan emosional.
\end{abstract}

Kata kunci: Siswa ,Membatik, Kreativitas, Ketahanan Emosional 


\section{PENDAHULUAN}

Anak-anak sering kali menjadi korban dari peristiwa atau kejadian yang tidak menguntungkan seperti bencana alam, konflik perang, masalah perceraian orang tua dan sebagainya. Jika anak-anak tidak mampu mengatasi dampak buruk dari peristiwa negatif tersebut, mereka dapat mengalami psikopatologi seperti stres, depresi, dan traumatik padahal masa anak-anak adalah masa yang sangat penting bagi perkembangan seseorang selanjutnya. Pada usia anak-anak pula seseorang dituntut untuk dapat merasakan bagaimana rasanya berhasil, baik di sekolah maupun di tempat bermain. Melalui tuntutan tersebut anak dapat mengembangkan suatu sikap rajin. Namun berbeda dengan anak yang tidak dapat meraih sukses karena mereka merasa tidak mampu (inferioritas). Anak yang mengalami kegagalan dan kesulitan akan menimbulkan rasa tertekan. Hal tersebut juga sangat berhubungan dengan penyaluran emosi anak. Saat ini banyak anak yang menyalurkan emosinya secara negatif, menyalurkan emosi pada hal yang berhubungan dengan keagresifan yang tinggi seperti bertengkar dengan temannya, memukul, atau menarik diri dari lingkungan. Hal tersebut seharusnya dapat dicegah karena dalam penyaluran emosi atau coping stress dapat dilakukan dan diajarkan dengan cara yang lebih baik dan positif, salah satunya adalah penyaluran emosi melalui kegiatan kreativitas.

Setiap orang dilahirkan dengan kemampuan untuk berkreasi dan menjadi kreatif. Namun beberapa faktor seperti lingkungan, aturan, dan kebiasaan cenderung mengubah perilaku kita untuk hidup terlalu serius dan berada dalam tekanan. Sedangkan kreativitas adalah sesuatu yang membutuhkan ruang dan waktu yang cukup untuk bisa diwujudkan sehingga terkadang sulit bagi kita untuk mengurangi tekanan-tekanan tersebut dan menyalurkan emosi kita melalui sesuatu yang positif dan berguna. Maka dari itu, dibutuhkan suatu aktivitas yang dapat merangsang kreativitas seseorang sedari dia masih kecil, karena sifat kreatif yang dianugerahkan Tuhan kepada kita sudah sepatutnya digali, dikembangkan, dan pada akhirnya dibagikan manfaatnya untuk orang lain. Kreativitas juga sangat dibutuhkan dalam mencapai sukses seseorang, dengan kreativitas kita dapat menciptakan sesuatu, mengolah, menggabungkan, mengubah, mengembangkan ide-ide yang mungkin sudah ada menjadi sesuatu yang baru yang belum pernah terpikirkan sebelumnya bahkan menciptakan sesuatu yang belum ada menjadi ada. Tidak hanya itu, sedari kecil seharusnya kita sudah diajarkan untuk menyalurkan, mengendalikan emosi, dan mengurangi tekanan emosi melalui suatu kegiatan, terutama kegiatan yang berhubungan dengan kreativitas.

Dalam penelitian yang dilakukan oleh Claudia Magele (2011), terdapat 6 cara seseorang mengendalikan emosi. Cara-cara tersebut adalah sebagai berikut: memahami keadaan emosional dan konsekuensinya; mengekang diri untuk mengontrol konsekuensi perilaku dan meresponnya melalui perilaku alternatif lain yang lebih konstruktif (misalnya jika emosi muncul bukan menyalurkannya dengan memukul tetapi dengan pergi berjalan-jalan); mengekspresikan emosi serta mengenali pengaturan emosional diri dapat membantu meningkatkan ketahanan emosi, jangan memendam dan mengabaikan emosi; mengalokasikan waktu untuk penyembuhan diri dari emosi dengan asosiasi diri; melakukan hal-hal positif, serta afirmasi diri yang positif. Anne Marie Evers (2010) mengemukakan Afirmasi (Inggris : Affirmation) atau dalam bahasa Indonesia diartikan dengan penegasan. Afirmasi mirip seperti doa, harapan atau cita-cita. Hanya saja afirmasi lebih terstruktur dibandingkan dengan doa dan lebih spesifik. Afirmasi diri dapat meningkatkan berpikir positif dan menghormati diri sendiri. Cara yang terakhir adalah memastikan anda memahami dan dapat menyelaraskan tujuan anda. Pertahankan sikap positif dan optimis dan disposisi. Berdasarkan penelitian tersebut dapat dilihat bahwa seseorang membutuhkan suatu wadah penyaluran emosi yang dapat menjadi alternatif penyaluran emosi-emosi negatif yang muncul.

Bangsa Indonesia adalah bangsa yang kaya akan ragam budaya dan seni, salah satunya adalah aktivitas membatik. Aktivitas membatik dapat dijadikan suatu wadah penyaluran emosi-emosi negatif, selain itu dalam aktivitas membatik terdapat unsur mempertahankan sikap positif dan optimis. Membatik adalah salah satu kegiatan yang berhubungan dengan kreativitas. Selain kreativitas, dari 
proses pembuatan batik hingga pada pemilihan corak dan motif batik, kita bisa mengambil banyak pelajaran. Pembuatan batik, khususnya batik tulis, yang memakan waktu cukup lama sampai 3 bulan mengandung makna kesabaran, ketelitian, dan ketelatenan. Dengan kesabaran, ketelitian, dan ketelatenan hasil yang didapat pun maksimal. Keindahan dan kualitas seni Batik buah dari kesabaran, ketelitian, ketelatenan serta ketekunan. Hal ini bisa juga diterapkan pada bagaimana seseorang menyalurkan emosi-emosi negatif yang ada pada dirinya. Selain itu hal tersebut juga dapat diterapkan bidang pekerjaan lainnya. Filosofi yang terkandung dalam seni membatik bisa kita gali dan kembangkan dalam kehidupan sehari-hari. Sebagaimana pola kehidupan masyarakat pembatik yang menjunjung tinggi nilai-nilai kekeluargaan, kegotongroyongan, kebersamaan, toleransi, dan budi pekerti, kesenian batik juga kental oleh nilai-nilai luhur yang patut kita serap. Harapannya melalui aktivitas membatik, seseorang dapat mengembangkan kreativitasnya dan melalui aktivitas membatik pula seseorang dapat menyalurkan dan mengendalikan emosi-emosi negatifnya.

Sudah banyak studi yang meneliti tentang ketahanan emosi pada anak-anak. Mulai tahun 1900-an banyak artikel berbasis penelitian yang menggambarkan bahwa kemampuan koping (dengan cara pengalihan pikiran, mengubah cara berpikir, olahraga dan mencari dukungan) dapat mengembangkan kemampuan anak-anak dalam mengatur emosi negatif mereka (Bernard, 2007). Dengan kemampuan menahan emosi ini anak-anak juga dapat mencapai cita-cita dan tujuan mereka, memecahkan masalah, memiliki keteguhan, tertata, serta dapat menjalin hubungan yang baik dengan sesama. Dengan memiliki ketahanan emosional yang tinggi pula anak-anak mampu untuk menghadapi situasi tertentu dengan lebih tenang dan menemukan serta memikirkan matang-matang dalam menemukan jalan keluar yang paling baik.

Penelitian yang dikemukakan oleh Brenner \& Salovey (1997) juga menunjukkan anak-anak yang sedang tumbuh dewasa memperlihatkan mereka lebih sering menggunakan strategi kognitif dan perilaku untuk mengatasi situasi yang tidak mereka inginkan, contohnya pada strategi perilaku adalah misalnya dengan cara berbicara pada seseorang atau melakukan sesuatu yang lain. Sedangkan penggunaan strategi kognitif misalnya dengan cara mengalihkan perhatian, berpikir positif, dan merenung memikirkan cara terbaik untuk keluar dari situasi tersebut. Penelitian tersebut juga menunjukkan bahwa cara menyalurkan emosi berbeda antara laki-laki dan perempuan. Laki-laki lebih suka untuk mengandalkan dukungan sosial seperti berbicara dengan orang lain, sedangkan perempuan lebih suka untuk fokus terhadap sensasi emosi internal mereka dan membuat perasaan-perasaan negatif tersebut hilang seperti berusaha untuk melupakan kejadian-kejadian yang menyakitkan. Dan yang terakhir, laki-laki lebih suka menyalurkan emosi dan stres mereka dengan kegiatan fisik.

Selain mengajarkan bagaimana menyalurkan emosi-emosi negatif dengan melakukan kegiatan kreativitas, para orangtua dapat pula mengembangkan kegiatan yang tidak hanya melatih ketahanan emosional anak-anak mereka serta merta mengenalkan dan mengajarkan kegiatan kreativitas untuk mencintai kebudayaan yang dimiliki oleh negaranya sendiri. Salah satu peninggalan seni dan budaya yang dimiliki Indonesia adalah Batik. Batik sebagai salah satu warisan seni budaya tidak hanya mengandung nilai estetika tetapi juga dapat mengembangkan jiwa kreativitas seseorang dan diharapkan membatik dapat dijadikan suatu wadah untuk menyalurkan emosi pada anak sehingga generasi muda kita dapat memiliki ketahanan emosi yang tinggi

Membatik pada dasarnya adalah suatu kegiatan kreativitas dimana membutuhkan waktu, ketenangan, kemampuan kognitif, dan motorik. Dengan aktivitas tersebut pula anak-anak dapat menyalurkan emosi-emosi negatif mereka. Asumsinya seseorang yang terbiasa membatik, memiliki kreativitas yang cukup tinggi. Seseorang yang mempunyai kreativitas yang baik memiliki cara yang adekuat dalam menyalurkan emosi negatifnya, sehingga diharapkan mempunyai ketahanan emosi yang baik pula. Namun, penelitian tentang hubungan kreativitas dengan ketahanan emosional masih relatif sedikit, bahkan penulis belum menemukan penelitian yang serupa dan dengan subjek siswa yang mengikuti ekstakulikuler membatik. 
Penulis melakukan penelitian di Yogyakarta. Hal ini karena daerah tersebut pernah mengalami bencana gempa bumi. Selain itu, Yogyakarta merupakan daerah sentra Batik. Gempa Yogya tahun 2006 dapat berdampak pada perkembangan ketahanan emosi anak. Banyak cara yang dapat dilakukan untuk melatih ketahanan emosi seseorang, sepatutnya pula para orangtua menanamkan dan mengajarkan pada anak-anak tentang bagaimana mengendalikan emosi serta penyalurannya kepada sesuatu yang lebih baik dan tidak berdampak negatif, salah satunya dengan melakukan kegiatan yang berhubungan dengan kreativitas seperti membatik. Di beberapa sekolah dasar di Indonesia, kegiatan membatik sudah diperkenalkan dan diajarkan kepada murid-muridnya. Kegiatan membatik tersebut dijadikan sebagai salah satu kegiatan ekstrakurikuler sekolah. Salah satu sekolah yang memiliki kegiatan ekstrakurikuler membatik diantaranya adalah Madrasah Ibtidaiyah Giriloyo 2 Yogyakarta. Subjek penelitian adalah siswa yang mengikuti ekstrakurikuler membatik di sekolah Kabupaten Bantul, Yogyakarta yang pernah mengalami bencana gempa bumi.

Dari latar belakang di atas penulis tertarik untuk mengetahui apakah ada hubungan antara kreativitas siswa yang mengikuti ektrakulikuler membatik dengan ketahanan emosi pada siswa di MI Giriloyo 2 Yogyakarta. Tujuan penelitian ini adalah untuk mengetahui bagaimana kreativitas dan ketahanan emosional pada siswa yang memiliki ekstrakurikuler membatik. Selain itu, penelitian ini juga ingin melihat adanya hubungan antara kreativitas dengan ketahanan emosi pada siswa dengan ekstrakurikuler membatik.

\section{METODE PENELITIAN}

Penelitian ini merupakan jenis penelitian korelasional. Metode pengumpulan data dilakukan dengan tes kreativitas figural (TKF) dan pemberian kuesioner ketahanan emosi. Tes Kreativitas Figural (TKF) merupakan adaptasi dari Circle Test yang dibuat oleh Torrance. TKF pertama kali digunakan di Indonesia oleh Utami Munandar pada tahun 1977. Dalam hasil penelitian tersebut diperoleh norma-norma baku dari TKF untuk siswa kelas 4 SD hingga siswa kelas 3 SMA, atau mencakup usia 10 sampai dengan 18 tahun. Kreativitas yang diukur dalam TKF memiliki pengertian sebagai kemampuan untuk membentuk kombinasi-kombinasi baru dari unsur-unsur yang diberikan yang tercermin dari kelancaran, kelenturan, dan orisinalitas dalam memberi gagasan serta kemampuan untuk mengembangkan, merinci, dan memperkaya (elaborasi) suatu gagasan.

Adapun aspek-aspek yang mendasari TKF sama dengan ciri-ciri kreativitas yang dikemukakan oleh Guilford, yaitu kelancaran berpikir, keluwesan berpikir, elaborasi dan originalitas (dalam Munandar dkk., 1988). Untuk mengukur kreativitas subjek dengan TKP, subjek diminta menggambar pada lingkaran-lingkaran yang ada pada lembar tes sebanyak-banyaknya dengan batas waktu 10 menit. Interpretasi data TKF selanjutnya dimasukkan ke dalam norma tingkat kreativitas dengan dibantu oleh seorang dosen yang juga psikolog.

Sedangkan kuesioner ketahanan emosional dibuat dengan menggunakan skala ketahanan emosional dengan karakter ketahanan emosional menurut Elizabeth Scott, M.S (2007). yaitu ; kesadaran emosional, ketekunan, lokus kontrol internal optimisme, dukungan, rasa humor, perspektif dan spiritualitas. Skala ini terdiri dari 50 item yang terbagi atas 35 item favorable dan 15 item unfavorable. Metode pengambilan data ini menggunakan dua skala psikologis yang memiliki karakteristik khusus yang membedakannya dari berbagai bentuk alat pengumpulan data yang lain dan untuk mengukur aspek-aspek afektif. Stimulusnya berupa pernyataan yang tidak langsung mengungkap atribut yang hendak diukur melainkan mengungkap indikator perilaku dari atribut yang bersangkutan (Saifuddin Azwar, 2004).

Pengumpulan data variabel ketahanan emosional ini menggunakan skala Likert, yang paling sering digunakan untuk mengukur sikap, pendapat, persepsi responden terhadap suatu objek 
(Kuncono, 2003). Dari hasil perhitungan didapatkan hasil penghitungan Alpha Cronbach sebesar 0,818 yang bermakna bahwa kuesioner tersebut reliabel.

\section{HASIL DAN PEMBAHASAN}

\section{Gambaran Subjek}

Dalam penelitian ini, subjek penelitian adalah siswa dan siswi kelas 4 sampai dengan kelas 6 MI Giriloyo Yogyakarta. Jika dilihat dari teori perkembangan sosial Erik Erikson (1902-1994), anakanak pada kelas 4 sampai dengan kelas 6 Sekolah Dasar sedang berada dalam tahapan childhood atau school age dengan komponen dasar industry vs inferiority. Pada tahapan tersebut anak sangat aktif mempelajari apa saja yang ada di lingkungannya.

Penelitian ini menggunakan 62 jumlah sampel yaitu siswa siswi MI Giriloyo 2 Yogyakarta dari kelas 4 hingga kelas 6 yang mengikuti ekstrakurikuler wajib membatik. Mereka melakukan proses membatik dari awal hingga akhir mulai dari: (1) ngemplong (mencuci kain mori); dilanjutkan dengan (2) pengeloyoran, yaitu memasukkan kain mori ke minyak jarak; (3) nyorek atau memola; (4) mbhatik merupakan tahap berikutnya, dengan cara menorehkan malam batik ke kain mori, dimulai dari nglowong (menggambar garis-garis diluar pola) dan isen-isen (mengisi pola dengan berbagai macam bentuk). Dalam proses isen-isen terdapat istilah nyecek, yaitu membuat isian dalam pola yang sudah dibuat dengan cara memberi titik-titik (nitik). Setelah itu, (5) nembok. Nembok adalah proses menutupi bagian-bagian yang tidak boleh terkena warna dasar, dengan menggunakan malam. (6) Medel, yaitu proses pencelupan kain yang sudah dibatik ke cairan warna secara berulang-ulang sehingga mendapatkan warna yang diingingkan. (7) Ngerok dan Mbirah; pada proses ini, malam pada kain dikerok secara hati-hati dengan menggunakan lempengan logam, kemudian kain dibilas dengan air bersih. Setelah itu kain diangin-anginkan. (8) Mbironi: yaitu menutupi warna biru dengan isen-isen pola yang berupa cecek atau titik dengan menggunakan malam. Selain itu, ada juga proses ngrining, yaitu proses mengisi bagian yang belum diwarnai dengan motif tertentu. Biasanya, ngringing dilakukan setelah proses pewarnaan dilakukan. (10) Menyoga; menyoga berasal dari kata soga. Adapun caranya adalah dengan mencelupkan kain ke dalam campuran warna cokelat tersebut. (11) Nglorod merupakan tahapan akhir dalam proses pembuatan sehelai kain batik.

Responden terbesar pada usia 12 tahun yakni sebanyak 22 responden (35,48\%), diikuti 20 responden (32,26\%) berusia 11 tahun, dan 10 responden berusia 10 tahun (16,13\%) kemudian 7 responden (11,29\%) berumur 13 tahun. Jumlah responden terkecil pada usia 9 tahun yakni sebanyak 1 responden (1,61\%). Responden laki-laki memiliki jumlah yang lebih banyak, yakni 33 responden (53,23\%) sedangkan perempuan sebanyak 29 responden (46,77\%). Responden terbesar memiliki jumlah paling banyak, yakni 23 responden (37,10\%) disusul responden kelas 5 sebanyak 20 responden (32,26\%) dan responden kelas 6 sebanyak 19 responden (30,64\%). Sedangkan responden (98,39\%) adalah suku jawa dan hanya 1 responden dari suku non-Jawa (1,61\%).

Salah satu kegiatan yang mencerminkan adanya kreativitas dan ketahanan emosional adalah aktivitas membatik. Seperti yang dikutip dari hasil wawancara dengan seorang guru batik di MI Giriloyo, ia menyebutkan bahwa dalam aktivitas membatik, anak-anak diajarkan untuk menggali kreativitas dan belajar akan mengendalikan emosi.

"Pada aktivitas membatik, para murid diajarkan untuk menuangkan ide-ide mereka menjadi sebuah hasil karya batik, selain itu dalam membatik juga murid-murid diajarkan kesabaran, ketekunan dan mengelola emosi mereka, karena tidak mudah menyelesaikan tugas membatik tersebut, canting dan malam yang panas serta kehati-hatian dalam menggambar dibutuhkan agar hasil batik mereka selesai dengan baik. Namun ketika mereka menyelesaikan hasil batik tersebut terdapat rasa bangga karena telah menyelesaikannya." (Sofana, 2012) 


\section{Kreativitas}

Kreativitas seringkali didefinisikan sebagai pengembangan dari ide-ide asli yang dapat berguna atau berpengaruh. Dalam perspektif ini kreativitas bukan hanya sekedar sebuah reaksi, tetapi juga berkontribusi untuk menciptakan perubahan atau sebuah evolusi. Dari segi penekanannya Rhode (dalam Akbar, 2001) kreativitas dapat didefinisikan ke dalam empat jenis dimensi sebagai Four P's of creativity, yaitu Person, Process, Press dan Product.

Definisi kreativitas dari dimensi person seperti dikemukakan oleh Guilford (dalam Akbar, 2001), yaitu creativity refers to the abilities that are characteristics of creative people. Definisi kreativitas yang menekankan dimensi Process seperti diajukan Munandar (dalam Akbar, 2001), yaitu creativity is a process that manifest in self in fluency, in flexibility as well in originalityof thinking. Dari dimensi Press, Amabile (dalam Akbar, 2001) mengemukakan bahwa creativity can be regarded as the quality of product or respons judged to be creatives by appropriate observes. Definisi kreativitas dari dimensi Product sebagaimana dikemukakan oleh Baron (dalam Akbar, 2001) adalah creativity is the ability to bring something new into existence.

Selanjutnya Feldman (dalam Craft, 2005) mendefinisikan kreativitas adalah: "the achievement of something remarkable and new, something which transforms and changes a field of endeavor in a significant way ...the kinds of things that people do that change the world." Menurut Munandar (dalam Akbar, 2001) kreativitas adalah kemampuan untuk membuat kombinasi baru, berdasarkan data, informasi atau unsur-unsur yang ada. Hasil yang diciptakan tidak selalu hal-hal yang baru, tetapi juga dapat berupa gabungan (kombinasi) dari hal-hal yang sudah ada sebelumnya. Kelancaran, Fleksibilitas, Orisinalitas, dan elaborasi merupakan ciri-ciri kreativitas yang berhubungan dengan kemampuan berpikir seseorang, semakin kreatif seseorang, ciri-ciri tersebut makin dimiliki (Munandar, 1992).

Ciri-ciri lain yang berkaitan dengan perkembangan afektif seseorang sama pentingnya agar bakat kreatif seseorang dapat terwujud. Ciri-ciri yang menyangkut sikap dan perasaan seseorang disebut ciri-ciri afektif dari kreativitas. Motivasi atau dorongan dari dalam untuk berbuat sesuatu, pengabdian, atau pengikatan diri terhadap suatu tugas termasuk ciri-ciri afektif kreativitas. Munandar (1992) juga menyebutkan ciri-ciri afektif lainnya yang sangat esensial dalam menentuan kreatif seseorang ialah rasa ingin tahu, tertarik terhadap tugas-tugas majemuk yang dirasakan sebagai tantangan, berani mengambil risiko untuk membuat kesalahan atau untuk dikritik oleh orang lain, tidak mudah putus asa, menghargai keindahan, mempunyai rasa humor, ingin mencari pengalamanpengalaman baru, dapat menghargai baik diri sendiri maupun orang lain dan sebagainya.

Adapun skor tertinggi yang diperoleh sampel penelitian dengan menyebarkan Tes kreativitas figural sebesar 135 sedangkan skor terendahnya adalah 88. Rata-rata skor 104 dengan simpangan baku sebesar 11. Keseluruhan skor tes kreativitas figural dikelompokkan menjadi 3 kelas yaitu tinggi, sedang dan rendah. Pembagian kelas tersebut berdasarkan norma kelompok. Perhatikan tabel 1 berikut.

Tabel 1 Distribusi Kelas Skor Tes Kreativitas Figural

\begin{tabular}{|c|c|c|}
\hline Skor TKF & Peringkat & Jumlah \\
\hline$x>115$ & Tinggi & 9 \\
\hline $93-115$ & Sedang & 44 \\
\hline$x<93$ & Rendah & 9 \\
\hline \multicolumn{2}{|c|}{ Jumlah } & 62 \\
\hline
\end{tabular}


Sampel yang memiliki skor tinggi yaitu lebih dari 115 sebanyak 9 siswa, sedangkan siswa yang memiliki skor rendah yaitu kurang dari 93 sebanyak 9 orang siswa. Sebagian besar sampel mempunyai kreativitas yang relatif sedang yaitu dengan skor 93 -115 sebanyak 44 siswa.

\section{Ketahanan Emosional}

Ketahanan emosional mengacu pada kemampuan seseorang untuk beradaptasi dengan situasi stres atau krisis (Scott, 2007). Ketahanan emosi adalah ketika seseorang mampu menahan dirinya untuk tidak marah, merasa sedih dan cemas ketika menghadapi situasi yang dianggap buruk baginya. Ini juga berarti bahwa orang tersebut mampu bangkit kembali dan menghindar dari kesulitan yang dialaminya (Bernard, 2006). Seseorang yang memiliki ketahanan emosional yang rendah memiliki waktu yang sulit ketika menghadapi stres dan perubahan dalam hidupnya.

Selain itu menurut Eric (2006) ketahanan emosional mengacu pada kemampuan anak untuk menghadapi dan mengatasi situasi yang menantang secara emosional dengan cara yang adaptif dan positif, sehingga mereka tidak hanya menyelesaikan situasi tersebut tetapi juga meningkatkan kapasitas mereka untuk menghadapi situasi serupa di masa mendatang. Secara emosional anakanak tangguh atau anak-anak yang memiliki ketahanan emosional yang tinggi adalah mampu mengatasi situasi emosional yang sulit dan bangkit kembali sedemikian rupa sehingga mereka siap untuk tantangan berikutnya dalam menjalani kehidupan.

Sedangkan skor tertinggi yang diperoleh sampel penelitian dengan menyebarkan kuesioner ketahanan emosional sebesar 88 sedangkan skor terendahnya adalah 57. Rata-rata skor 73 dengan simpangan baku sebesar 8. Keseluruhan skor ketahanan emosional dikelompokkan menjadi 3 kelas yaitu tinggi, sedang dan rendah. Pembagian kelas tersebut berdasarkan norma kelompok. Untuk lebih jelasnya, lihat tabel 2 berikut.

Tabel 2 Distribusi Kelas Skor Ketahanan Emosional

\begin{tabular}{|c|c|c|}
\hline Skor TKF & Peringkat & Jumlah \\
\hline$x>81$ & Tinggi & 8 \\
\hline $65-81$ & Sedang & 45 \\
\hline$x<65$ & Rendah & 9 \\
\hline \multicolumn{2}{|c|}{ Jumlah } & 62 \\
\hline
\end{tabular}

Sampel yang memiliki skor tinggi yaitu lebih dari 81 sebanyak 8 siswa, sedangkan siswa yang memiliki skor rendah yaitu kurang dari 65 sebanyak 9 orang siswa. Sebagian besar sampel mempunyai ketahanan emosional yang relatif sedang yaitu dengan skor 65 -81 sebanyak 45 siswa.

\section{Hubungan antara Kreativitas dan Ketahanan Emosi}

Berdasarkan hasil analisis hubungan korelasi bivariat product moment dengan bantuan program SPSS 19.0 for windows antara kreativitas dengan ketahanan emosional diperoleh nilai korelasi sebesar 0,184 dan $\mathrm{p}=0,153$. Hal ini menunjukkan bahwa hipotesis nihil (H0) yang menyatakan "tidak terdapat Hubungan yang signifikan antara kreativitas dengan ketahanan emosional pada siswa MI Giriloyo 2 Yogyakarta" diterima. Sedangkan Hipotesis alternatif (Ha) yang menyatakan "terdapat Hubungan yang signifikan antara kreativitas membatik dengan ketahanan emosional pada siswa MI Giriloyo 2 Yogyakarta” ditolak. 
Adapun hasil uji korelasi kedua skala adalah sebagai berikut.

Tabel 3 Hasil Uji Korelasi

\begin{tabular}{clcc}
\multicolumn{5}{c}{ Correlations } \\
\hline & ER & TKF \\
\hline \multirow{2}{*}{ ER } & Pearson Correlation & 1 & .184 \\
& Sig. (2-tailed) & & .153 \\
& $\mathrm{~N}$ & 62 & 62 \\
TKF & Pearson Correlation & .184 & 1 \\
& Sig. (2-tailed) & .153 & \\
& $\mathrm{~N}$ & 62 & 62 \\
\hline
\end{tabular}

Berdasarkan hasil analisis data dengan menggunakan Product Moment Pearson dengan SPSS 19 for Windows disimpulkan bahwa hipotesis alternatif (Ha): "terdapat hubungan yang signifikan antara kreativitas membatik dengan ketahanan emosional pada siswa MI Giriloyo 2 yogyakarta” ditolak, dengan diperoleh nilai korelasi sebesar 0,184 dan $\mathrm{p}=0,153$ yang menunjukkan hasil tes kreativitas figural dan tes ketahanan emosional yang diberikan kepada subjek penelitian memiliki hubungan yang sangat rendah. Sehingga dari hasil penelitian yang telah diperoleh dapat disimpulkan bahwa, fenomena yang menyatakan "kreativitas memiliki hubungan yang signifikan dengan ketahanan emosional pada siswa dengan ekstrakurikuler membatik" tidak terbukti.

Adapun koefisien korelasi dijelaskan dari tabel 4 berikut.

Tabel 4 Koefisien Korelasi

\begin{tabular}{cl}
\hline Korelasi & \multicolumn{1}{c}{ Tingkat Hubungan } \\
0 & Tidak berkorelasi \\
$0,01-0,20$ & Sangat rendah \\
$0,21-0,40$ & Rendah \\
$0,41-0,60$ & Agak Rendah \\
$0,61-0,80$ & Cukup \\
$0,81-0,99$ & Tinggi \\
1 & Sangat Tinggi \\
\hline
\end{tabular}

Jika dilihat lebih jauh, kreativitas dan ketahanan emosional sama-sama memiliki ciri kognitif dan afektif. Adapun ciri kognitif dari kreativitas menurut Munandar (1992) seperti kelancaran untuk menuangkan ide-ide (fluency), kemampuan untuk memberikan gagasan-gagasan yang beragam (flexibility), kemampuan untuk memberikan gagasan-gagasan yang secara statisik unik dan langka untuk populasi tertentu serta kemampuan untuk melihat hubungan-hubungan baru, atau membuat kombinasi-kombinasi baru anara macam-macam unsur/bagian (originality), serta kemampuan untuk mengembangkan, merinci dan memperkaya suatu gagasan (elaborasi). Ciri kognitif dari ketahanan emosional adalah lokus kontrol internal, cenderung memandang segala persoalan dalam hidupnya sebagai sebuah tantangan hidup dan menghadapinya dengan tindakan nyata, memahami apa yang kita rasakan dan mengapa kita memiliki perasaan itu serta menghilangkan pikiran-pikiran negatif dan mengalihkannya kepada pikiran yang lebih positif. Untuk mengelola pikiran-pikiran negatif, seseorang yang memiliki fungsi kognitif yang baik maka akan lebih mudah menuangkan segala sesuatunya menjadi suatu bentuk karya kreativitas. Seperti yang dikemukakan oleh Solso (dalam Galuh, 2012), 
kreativitas adalah aktivitas kognitif yang menghasilkan cara pandang baru terhadap suatu masalah atau situasi.

Selain ciri kognitif, terdapat ciri afektif yang dimiliki oleh kreativitas dan ketahanan emosional, yaitu rasa ingin tahu, tertarik terhadap tugas-tugas majemuk yang dirasakan sebagai tantangan, berani mengambil risiko untuk membuat kesalahan atau untuk dikritik oleh orang lain, tidak mudah putus asa, menghargai keindahan, mempunyai rasa humor, ingin mencari pengalamanpengalaman baru serta dapat menghargai baik diri sendiri maupun orang lain. Ciri afektif tersebut yang menunjukkan adanya hubungan atau irisan antara kreativitas dengan ketahanan emosional.

Penelitian tentang ketahanan emosional yang telah dilakukan sebelumnya lebih banyak tentang beberapa kondisi merugikan seperti kerugian sosial ekonomi dan risiko terkait (Garmezy, 1991, 1995; Rutter, 1979; Werner \& Smith, 1982, 1992), penyakit mental orang tua (Masten \& Coatsworth, 1995, 1998), penganiayaan (Beeghly \& Cicchetti, 1994; Cicchetti \& Rogosch, 1997; Cicchetti, Rogosch, Lynch, \& Holt, 1993; Moran \& Eckenrode, 1992), kemiskinan masyarakat kota dan kekerasan (Luthar, 1999; Richters \& Martinez, 1993), penyakit kronis (Wells \& Schwebel, 1987) dan peristiwa bencana besar (O'Dougherty-Wright, Masten, Northwood, \& Hubbard, 1997).

Penelitian ketahanan emosional pada anak-anak bahwa faktor eksternal lebih mempengaruhi katahanan emosional pada anak-anak (Masten \& Garmezy, 1985). Penelitian selanjutnya menghasilkan penggambaran tiga set faktor yang terlibat dalam ketahanan emosional yaitu (1) atribut dari anak itu sendiri, (2) aspek keluarga mereka, dan (3) karakteristik lingkungan sosial yang lebih luas (Masten \& Garmezy, 1985; Werner \& Smith, 1982, 1992).

Dengan demikian dapat dinyatakan bahwa kreativitas tidak memiliki hubungan yang signifikan dengan ketahanan emosional dikarenakan variabel lain yang merupakan faktor internal dan eksternal subjek yang tidak diteliti dalam penelitian ini. Faktor internal atribut subjek seperti locus of control, spritual, dan pengalaman subjek dalam memecahkan masalah ditenggarai memengaruhi ketahanan emosi subjek. Subjek penelitian ini adalah anak-anak MI Giriloyo 2 dari kelas 4 sampai dengan kelas 6. Jika dilihat dari teori perkembangan Erikson (1902-1994) dalam Santrock (2008), pada tahapan ini, anak-anak memiliki dorongan untuk mengetahui dan berbuat terhadap lingkungannya sangat besar, tetapi di pihak lain karena keterbatasan-keterbatasan kemampuan dan pengetahuannya kadang-kadang dia menghadapi kesukaran, hambatan bahkan kegagalan. Hasil hubungan yang rendah juga dipengaruhi oleh subjek dalam tahapan ini, karena dalam tahapan ini subjek masih memiliki keterbatasan-keterbatasan dalam dirinya sehingga dibutuhkan dorongan, perhatian, serta pembelajaran agar kedua variabel tersebut dapat terbentuk dengan baik karena kedua variabel tersebut sangat dipengaruhi oleh proses belajar dan pengalaman seseorang. Artinya subjek masih belum berpengalaman dlam memecahkan masalah termasuk ketika menghadapi kondisi yang tidk menguntungkan.

Menurut Piaget (1977) Dalam upaya memahami alam sekitarnya, anak sekolah usia dasar tidak lagi terlalu mengandalkan informasi yang bersumber dari panca indera, karena ia mulai mempunyai kemampuan untuk membedakan apa yang tampak oleh mata dengan kenyataan sesungguhnya. Hanya saja, apa yang dipikirkan oleh anak masih terbatas pada hal-hal yang ada hubungannya dengan sesuatu yang konkret, suatu realitas secara fisik, benda-benda yang benar-benar nyata. Sebaliknya, benda-benda atau peristiwa-peristiwa yang tidak ada hubungannya secara jelas dan konkret dengan realitas, masih sulit dipikirkan oleh anak. Selain itu anak masih mengalami trial and error untuk memecahkan masalahnya

Dari tahapan perkembangan kognitif tersebut, kecenderungan belajar anak usia sekolah dasar memiliki tiga ciri, yaitu: (1) konkret; konkret mengandung makna proses belajar beranjak dari hal-hal yang konkret yakni yang dapat dilihat, didengar, dibaui, diraba, dan diotak atik, dengan titik penekanan pada pemanfaatan lingkungan sebagai sumber belajar. Pemanfaatan lingkungan akan 
menghasilkan proses dan hasil belajar yang lebih bermakna dan bernilai, sebab siswa dihadapkan dengan peristiwa dan keadaan yang sebenarnya, keadaan yang alami, sehingga lebih nyata, lebih faktual, lebih bermakna, dan kebenarannya lebih dapat dipertanggungjawabkan. (2) Integratif: pada tahap usia sekolah dasar, anak memandang sesuatu yang dipelajari sebagai suatu keutuhan, mereka belum mampu memilah-milah konsep dari berbagai disiplin ilmu. Hal ini melukiskan cara berpikir anak yang deduktif yakni dari hal umum ke bagian demi bagian. (3) Hierarkis: pada tahapan usia sekolah dasar, cara anak belajar berkembang secara bertahap mulai dari hal-hal yang sederhana ke halhal yang lebih kompleks. Sehubungan dengan hal tersebut, maka perlu diperhatikan mengenai urutan logis, keterkaitan antar materi, dan cakupan keluasan serta kedalaman materi. Sehingga proses belajar, pengalaman dan bantuan serta dukungan dari lingkungan masih sangat dibutuhkan. Dengan demikian faktor eksternal seperti dukungan keluarga maupun lingkungan sosial sekolah berperan dalam memengaruhi ketahanan emosi subjek.

Penelitian ini tidak menggali ketahanan emosi subjek dengan metode wawancara maupun melakukan observasi ketika subjek mendapatkan kendala pada saat membatik yang cukup membutukan kesabaran dan ketekunan.

\section{SIMPULAN}

Mengacu pada hasil analisis data yang telah dilakukan, maka dapat disimpulkan bahwa siswa MI Giriloyo 2 yang memiliki kegiatan ekstrakurikuler membatik, sebagian besar mempunyai kreativitas yang relatif sedang yaitu dengan skor $93-115$ sebanyak 44 siswa dari 62 siswa. Demikian juga dengan skor ketahanan emosionalnya relatif sedang, yaitu dengan skor 65 -81 sebanyak 45 siswa dari 62 siswa. Kreativitas tidak memiliki hubungan yang signifikan dengan ketahanan emosional dengan koefisien korelasi yang sangat rendah. Faktor internal subjek seperti locus of control tingkat spiritual, pengalaman dalam memecahkan masalah, serta faktor eksternal seperti dukungan keluarga dan sekolah yang tidak diteliti dalam penelitian ini, sepertinya yang lebih berkorelasi dengan ketahanan emosional.

Berdasarkan temuan penelitian, maka saran yang dapat dikemukakan adalah sebagai berikut. Penelitian selanjutnya dapat menambahkan atau menggunakan variabel penelitian lainnya seperti locus of control, self efficacy, prestasi belajar, dukungan keluarga, lingkungan sosial, pola asuh, spiritualitas dan lain-lain. Selain itu juga diharapkan dapat menambahkan teori-teori yang baru sebagai acuan yang baik sebagai teori pendukung maupun pembuatan skala yang digunakan sebagai acuan, selain itu juga dapat menggunakan subjek yang berbeda, latar belakang pendidikan, latar usia dan lainnya, sehingga dapat diperoleh hasil yang menambah ilmu pengetahuan. Metode wawancara dan observasi sebaiknya dilakukan untuk mendapatkan hasil penelitian yang lebih objektif.

Bagi para guru dan para siswi, ekstrakurikuler membatik diharapkan dapat terus meningkatkan kreativitas dengan mengembangkan kegiatan membatik yang didasari oleh unsur-unsur yang dapat meningkatkan kreativitas seperti kelancaran, keluwesan, orisinalitas, dan elaborasi. Tidak harus terpaku pada pola yang sudah ada. Unsur-unsur afektif seperti rasa ingin tahu, tertarik terhadap tugastugas majemuk yang dirasakan sebagai tantangan, berani mengambil risiko untuk membuat kesalahan atau untuk dikritik oleh orang lain, tidak mudah putus asa, menghargai keindahan, mempunyai rasa humor, ingin mencari pengalaman-pengalaman baru, dapat menghargai baik diri sendiri maupun orang lain dan sebagainya juga harus terus ditingkatkan agar kreativitas dan ketahanan emosional pada anak dapat terus ditingkatkan 


\section{DAFTAR PUSTAKA}

Batik, the Traditional Fabric of Indonesia. Retrieved Desember, 28, from

Bernard, M. (2006). Emotional Resilience:Implications for You Can Do It! Education Theory and Practice. Long Beach: California State University.

Debby. (2012). STRES vs KETAHANAN EMOSIONAL. Retrivied July, 21, from http://www.matawanita.com/index.php/cantik-bugar/kesehatan/1778-stres-vs-ketahananemosional

Earvolino-Ramirez, M. (2007). Resilience: A Concept Analysis. 42. 2. 73-82. Retrieved May 10, 2012, from Proquest.

Eric. (2006). The Emotional Resilience in Infancy \& Childhood Working Group. Retrivied May 13, 2010 from http://www.psych.usyd.edu.au/eric/

Hawadi, R. A., Wihardjo,R. S. D., Wiyono, M. (2001). Kreativitas. Jakarta: Grasindo. http://www.expat.or.id/info/batik.html

Kelly, O. (2010). Coping Retrieved April, 10, from http://ocd.about.com/od/glossary/g/Coping_Glossary.htm

Kiehn, M. (2003). Development of Music Creativity among Elementary School Students. Journal of Research in Music Education, 51.4, 278-288. Retrieved December 28, 2011, from Proquest.

Kuncono. (2004). Analisis Butir. Jakarta: BPP - Y.A.I.

Lahey, B. B. (2007). Psychology: An Introduction, Ninth Edition. New York: McGraw Hill.

Lasky, D., Yoon, S. (2011). Making Space for the Act of Making: Creativity in the Engineering Design Classroom. Science Educator, 20.1, 34-43. Retrieved December 28, 2011, from Proquest.

Megele, C. (2011). How to Develop Emotional Resilience. Community Care, 1857, 30. Retrieved January 14, 2012, from Proquest.

Piaget, J. (1977). Gruber, H.E.; Voneche, J.J. eds. The essential Piaget. New York: Basic Books.

Runco, M. (2004). Creativity. Annual Review of Psychology, 55, 657-87. Retrieved December 28, 2011, from Proquest.

Saifuddin, A. (2004). Realibilitas dan Validitas. Yogyakarta: Pustaka Pelajar.

Santrock, J. W. (2008). A topical approach to life-span development (4th ed.). New York City: McGraw-Hill.

Scott, E. (2007). The Traits, Benefits and Development of Emotional Resilience. Retrieved January, 14, from http://stress.about.com/od/understandingstress/a/resilience.html

Seniati, L., Yulianto, A., Setiadi, B.N. (2005). Psikologi Eksperimen. Jakarta: Gramedia. 
Taniredja, T and Mistafidah, H. (2011). PENELITIAN KUANTITATIF (Sebuah Pengantar). Bandung: Alfabeta.

Wulandari, A. (2011). Batik Nusantara : Makna Filosofis, Cara Pembuatan dan Industri Batik. Yogyakarta : Penerbit Andi. 